\title{
Article \\ Effect of Informed Conditions on Sensory Expectations and Actual Perceptions: A Case of Chocolate Brownies Containing Edible-Cricket Protein
}

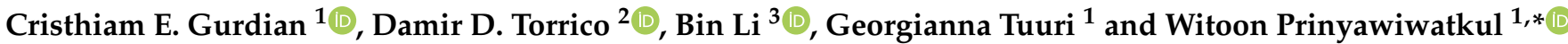 \\ 1 School of Nutrition and Food Sciences, Louisiana State University Agricultural Center, \\ Baton Rouge, LA 70803, USA; cgurdi3@lsu.edu (C.E.G.); gtuuri@agcenter.lsu.edu (G.T.) \\ 2 Department of Wine, Food and Molecular Biosciences, Faculty of Agriculture and Life Sciences, \\ Lincoln University, Lincoln 7647, New Zealand; damir.torrico@lincoln.ac.nz \\ 3 Department of Experimental Statistics, Louisiana State University Agricultural Center, \\ Baton Rouge, LA 70803, USA; bli@lsu.edu \\ * Correspondence: wprinya@lsu.edu
}

\section{check for} updates

Citation: Gurdian, C.E.; Torrico, D.D.; Li, B.; Tuuri, G.;

Prinyawiwatkul, W. Effect of

Informed Conditions on Sensory

Expectations and Actual Perceptions:

A Case of Chocolate Brownies

Containing Edible-Cricket Protein.

Foods 2021, 10, 1480. https://

doi.org/10.3390/foods 10071480

Academic Editor:

Jean-Xavier Guinard

Received: 20 May 2021

Accepted: 21 June 2021

Published: 25 June 2021

Publisher's Note: MDPI stays neutral with regard to jurisdictional claims in published maps and institutional affiliations.

Copyright: (c) 2021 by the authors. Licensee MDPI, Basel, Switzerland. This article is an open access article distributed under the terms and conditions of the Creative Commons Attribution (CC BY) license (https:/ / creativecommons.org/licenses/by/ $4.0 /)$.
Abstract: Currently, many consumers are reluctant to consume edible-cricket protein (ECP). Chocolate brownie (CB) formulations without (WO) and with $(\mathrm{W}) 6 \% w / w \mathrm{ECP}$ (CBWO and CBW, respectively) were presented under two informed conditions: formulated without ECP (ECP-) and formulated with $\mathrm{ECP}+$ benefits $(\mathrm{ECP}+)$. $\mathrm{CBWO}-(\mathrm{CBWO}$ presented with the "ECP -" claim), $\mathrm{CBWO}+$ (CBWO presented with the "ECP+" claim), CBW- (CBW presented with the "ECP-" claim), and $\mathrm{CBW}+(\mathrm{CBW}$ presented with the "ECP+" claim) were evaluated by 210 consumers for expected and actual attribute liking, and after-tasting consumption and purchase intent. Multi-way ANOVA, principal component analysis, and agglomerative clustering examined liking. Cochran-Q tests compared actual-liking profiles, purchase and consumption intent. Before tasting, $\mathrm{CBW}-$ obtained the lowest appearance liking, flavor liking was higher for $\mathrm{ECP}$ - than for $\mathrm{ECP}+$ for either formulation, and $\mathrm{ECP}+$ decreased aroma and overall liking only for CBWO. After tasting, CBWO had higher liking than CBW (except for aroma) for either informed condition. Regardless of the formulation, $\mathrm{ECP}-$ and $\mathrm{ECP}+$ had similar actual liking. Nevertheless, ECP+ prevented negative disconfirmation for both formulations while ECP - decreased texture liking (for CBWO) and all liking (for CBW) upon tasting. Females' consumption intent was higher for CBWO regardless of the informed condition, but CBW+ achieved a similar purchase intent to CBWO- for both genders.

Keywords: alternative insect protein; cognitive cue; consumer behavior; entomophagy; insect consumption

\section{Introduction}

One billion people presently experience inadequate protein intake and protein-energy malnutrition, resulting in impaired growth, development, and health. The world population is expected to reach 9.6 billion by 2050 , translating into a $70 \%$ increase in the actual global food demand. Hence, the development of sustainable and nutrient-dense foods from alternative sources is needed to overcome food insecurity [1]. While food insecurity is the main concern in developing countries given the projected increase in the global population, for developed countries such as the United States, food insecurity is rather a minor issue. Instead, for industrialized countries, food safety and environmental sustainability of the food production system are the main topics driving the current and future health problems associated with foods [2].

The animal-based food production system requires more environmental resources and generates more pollution than edible-insect production [3]. Incorporation of edible insects rich in protein, such as crickets, into human diets, can offer sustainable alternatives to conventional protein sources, because insects are more efficient in the body-mass conversion of feeding [4]. 
About 2000 species of insects are edible, but only around 113 countries worldwide practice entomophagy, or the eating of insects [5]. The nutritional profile and quality of insects depend on various factors including the species, developmental stage, origin, and diet, etc. [6]. The protein content in edible insects ranges from $35-61 \%$ on a dry basis [7], surpassing the protein content [2] of popular plant-derived sources (e.g., soybeans, beans, lentils), and making it comparable to that of conventional high-quality animal-derived sources [8-10].

Rumpold and Schlüter [7] reported that members of the Orthoptera species had superior protein content (upper range of $77.13 \%$ dry basis) compared to the maximum protein content observed in plants (35.8\% dry basis in soybeans). A feeding trial evaluating crickets' protein quality found equal or improved amino acid content of the cricket meals compared to soy protein [11]. Köhler et al. [12] found that Bombay locust, scarab beetle, house cricket, and mulberry silkworm from Thailand were all high in protein. Oibiokpa et al. [13] assessed the protein quality of moth caterpillar, termite, cricket, and grasshopper in rat diets, and reported that crickets had the highest amino acid score (0.91), protein efficiency ratio (PER; 1.78), net protein ratio (3.04), biological value (93.02\%), and protein digestibility corrected for amino acid score (0.73). Crickets were superior to casein in terms of PER (1.78 vs. 0.86 ) and biological value (93.02 vs. 73.45 ) and similar in net protein ratio (3.04 vs. 2.74 ) and NPU (75.20 vs. 72.42$)$, but had lower true digestibility (80.82 vs. 98.19$)$, respectively.

Edible insects are also rich (10-60\% dry basis) in fat and lipids $[4,14]$ with a lower omega 6:omega 3 ratio. Most edible insects are good sources of energy, essential amino acids, trace elements, and minerals providing B-complex vitamins [14].

Despite the nutritional and environmental advantages of entomophagy, there is still a significant aversion to insects as foods $[15,16]$ associated with food neophobia, poorly perceived sensory quality, or negative product-elicited emotions mainly in the Western world [17]. Efforts to change attitudes have resulted in food products yielding poor sensoryliking and adverse emotional reactions [18]. However, consumers' preferences may be altered over time through repeated exposure in which the social, religious, and cultural environments play a crucial role depending on age, gender, education, economic status, and degree of health consciousness [19].

The consumption of edible insects in Western culture is very limited [20]. Food safety concerns (microbial and chemical health risks) are among the main obstacles for introducing entomophagy to Western diets even for consumers' willingness to consume edible insects and/or edible insect ingredients [9]. However, previous research studying the perception of insect ingredients among Westerners has shown that depending on the product sensory profile [21], consumers may be able to repeat insect consumption if they enjoyed a previous eating experience. Moreover, hedonic claims [22] and informative sessions regarding edible insects (including their safety regulations and benefits) [23] seemed to improve familiarity and alleviate negative preconceptions about entomophagy. Fischer and Steenbekkers [24] reported that Westerners were more receptive to crickets, mealworms, and grasshoppers than other edible insects. On the other hand, Ardoin and Prinyawiwatkul [15] found that U.S. consumers were more willing to try insect ingredients in protein/energy bars, chips/snack crackers and protein shakes, but bakery/cereal products and snacks/candy also obtained positive willingness to try by over $50 \%$ of the survey respondents. In their study, unfamiliarity with edible insects was the most limiting factor for the willingness to consume insects, but communicating benefits derived from entomophagy positively impacted the willingness to try for all products.

The science behind edible insects is still pioneering in the Western world. The development of acceptable products containing insect proteins could be achieved with a thorough understanding of consumers' expectations, needs, sentiments, and drivers of liking for this market niche. Introducing edible-cricket protein as a processed ingredient [6] in a familiar product [21,25], such as chocolate brownies, while providing information about the sustainability and health benefits of entomophagy may alleviate consumer reluctance to consume edible insects. 
To our knowledge, the combined effect of providing or withholding information about the presence and benefits (sustainability + nutritional quality) of ECP on consumer acceptability, willingness to consume and to purchase chocolate brownies with and without ECP has not been studied. Hence, this study compared the sensory acceptability, consumption intent, and purchase intent of chocolate brownies without (CBWO) and with $6 \%$ ECP $(\mathrm{CBW})$ when presented under two informed conditions regarding the absence $(\mathrm{ECP}-)$ or presence of ECP and its environmental and nutritional quality associated benefits $(\mathrm{ECP}+)$.

\section{Materials and Methods}

\subsection{Chocolate Brownie Samples Preparation}

Betty Crocker fudge chocolate brownie batter mixes (General Mills Sales, Inc., Minneapolis, MN, USA) containing sugar, enriched bleached flour (wheat flour, niacin, iron, thiamin mononitrate, riboflavin, folic acid), cocoa processed with alkali, palm oil, corn syrup, corn starch and $2 \%$ or less of: carob powder, salt, canola oil, and artificial flavor, USDA grade A large-white eggs (Great Value, Walmart Stores, Inc., Bentonville, AR, USA), and Wesson canola oil (Conagra Brands, Chicago, IL, USA) were purchased at Walmart Supercenter (Baton Rouge, LA, USA). Griopro edible cricket protein (ECP) powder (All Things Bugs LLC, Midwest City, OK, USA) made of whole crickets (Acheta domesticus and Gryllodes sigillatus) was purchased online from www.cricketpowder.com (accessed on 28 January 2019). Batches of each chocolate brownie formulation (without ECP, CBWO, and with $6 \% w / w \mathrm{ECP}, \mathrm{CBW})$ were prepared following the cooking instructions provided on the batter mix and scaled up to provide sufficient samples for the consumer test. The $6 \% w / w$ ECP concentration was selected based on a preliminary trial with 25 subjects. A range of concentrations $(3-10 \% w / w)$ was tested for which $6 \% w / w$ yielded a recognizable difference compared to control ( $0 \% \mathrm{ECP})$ in half of the subjects but without largely compromising the sensory acceptability or identifying a particular sensory characteristic that would reveal the identity of the ingredient. For each batch, eggs (875 g), water (258 g), canola oil (621 g), and batter mix (3128 g) were stirred together in a Globe SP20 commercial food mixer (Globe Food Equipment CO, Dayton, OH, USA) at speed 2. For CBW, ECP (312 g) was additionally mixed with the other ingredients. The mixture was then poured into a $45.7 \mathrm{~cm} \times 66 \mathrm{~cm}$ aluminum pan and baked in a pre-heated OV310G mini rotating rack oven (Baxter Mfg, a Division of ITW FEG, LLC, Orting, WA, USA) at $325^{\circ} \mathrm{F}$ for $52 \mathrm{~min}$. Batches from both formulations were stored separately at room temperature in sealed plastic containers overnight until the analyses and consumer test.

\subsection{Sensory Evaluation}

\subsubsection{Subjects}

Untrained subjects 18 years of age and older $(n=210,98$ males and 112 females) were recruited at Louisiana State University (LSU), Baton Rouge, Louisiana, USA, and screened for: (1) willingness to evaluate test samples that contain edible-cricket protein (ECP) powder, (2) self-report on no allergies or adverse reactions to the test samples, (3) not having impaired vision/color blindness or taste/smell disorders that would compromise their sensory evaluations, and (4) being regular consumers (at least once per month) of chocolate brownies based on self-reported responses. All participants were informed of any allergens present in the test samples. Subsequently, subjects agreed with and signed a consent form included in the research protocol approved (IRB \# HE 18-9 and \# HE 18-22) by the LSU Agricultural Center Institutional Review Board.

\subsubsection{Consumer Test}

On the day of the study, chocolate-brownie samples were cut into $3 \mathrm{~cm}$ cubes and placed in $2 \mathrm{oz}$. clear plastic-lidded cups labeled with three-digit blinding codes. Each panelist evaluated all four treatments (before and after tasting) in one session, cleansing their palate with unsalted crackers and water before the first sample and in between samples (when instructed to taste). The consumer test took place in partition booths 
equipped with white lights in the Sensory Services Laboratory at LSU under a controlled environment (ca. $25^{\circ} \mathrm{C}$ ). After the evaluation, participants were compensated with soft drinks and/or brewed coffee.

\subsubsection{Questionnaire}

Computer-based questionnaires were administered to panelists and their responses were collected using Qualtrics software (Qualtrics, Provo, UT, USA). Chocolate-brownie treatments (Figure 1) were presented simultaneously, and consumers were instructed to evaluate them in a monadic-sequential order following screen instructions, following a complete randomized block design.
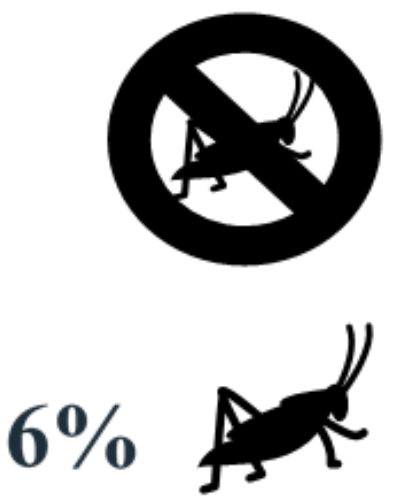
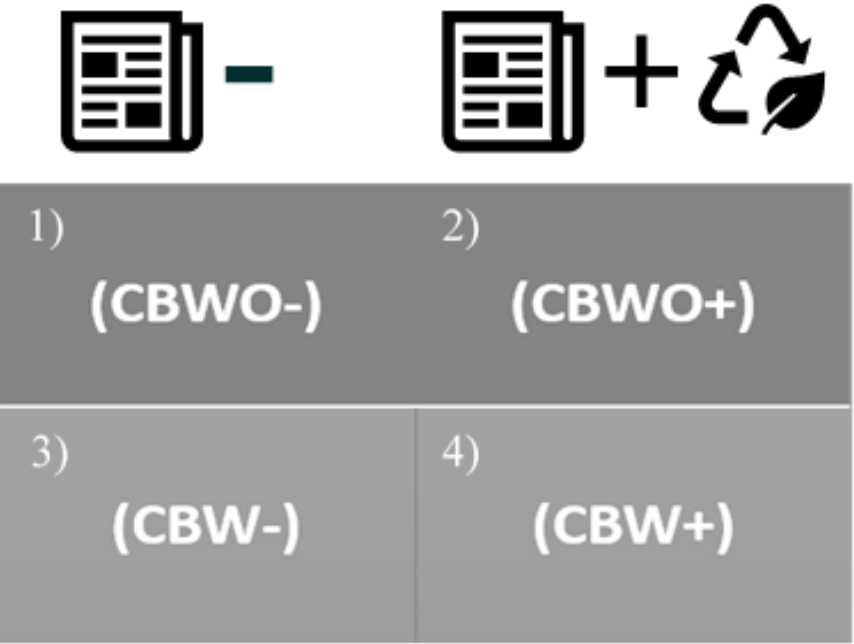

Figure 1. Treatments presented under informed conditions. ECP: Edible-cricket protein. CB: Chocolate brownies. WO: Without; W: With. ECP-: “No ECP” informed condition. ECP+: “Contains ECP + benefits" informed condition. (1) CBWO-: chocolate brownies without ECP (CBWO) presented under the ECP - informed condition; (2) CBWO+: CBWO presented under the ECP+ informed condition; (3) $\mathrm{CBW}-$ : chocolate brownies with 6\% ECP (CBW) presented under the ECP - informed condition; (4) CBW+: CBW presented under the ECP+ informed condition.

Before evaluating a chocolate brownie (CB) sample without (WO) or with (W) edible cricket protein (ECP) (CBWO and CBW, respectively), an informed condition regarding the sample's absence of ECP powder (ECP-: "please closely observe the brownie, this brownie does not contain ECP") or the sample's presence of ECP powder accompanied by ECP picture (Figure 2) and its nutritional and environmental benefits (ECP+: "please closely observe the brownie, this brownie contains ECP. Edible insects are safe to eat and are considered a sustainable source of high-quality protein and other nutrients. Edible insect production has less negative environmental impact than traditional livestock production. An estimated 2 billion people worldwide consume edible insects") was disclosed to the subjects. Then, the participants: (1) rated their expected liking (before tasting) with a 9-point-hedonic scale (left-anchored dislike extremely and right-anchored like extremely) for appearance, aroma, texture, overall flavor, and overall liking (OL), (2) rated their actual liking (upon tasting) with the abovementioned scale for aroma, texture, overall flavor, and OL, and (3) expressed their willingness to consume and to purchase the sample if it were commercially available with a binomial scale (Yes or No) for each of the four treatments: CBWO- (no ECP in formulation presented with "no ECP" claim), CBWO+ (no ECP in formulation presented with "ECP+benefits" claim), CBW- (formulation with ECP presented with "no ECP" claim), and CBW+ (formulation with ECP presented with "ECP+benefits" claim). 


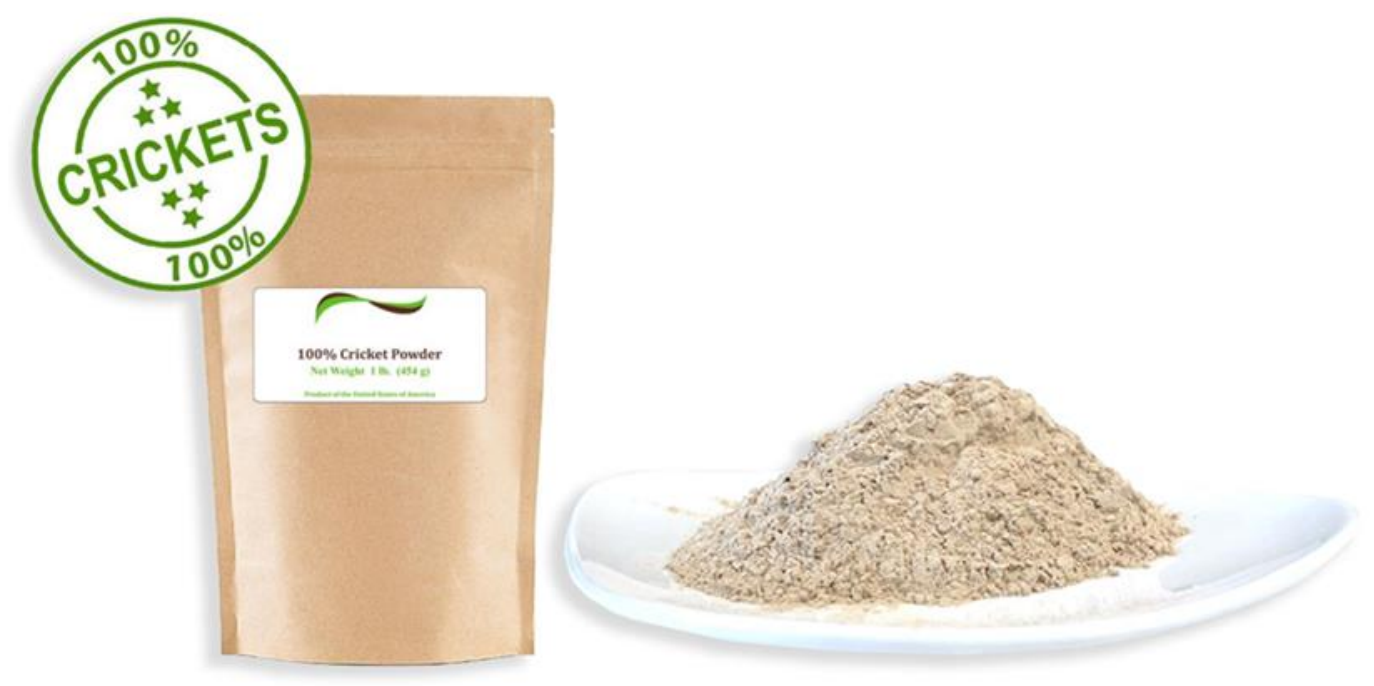

Figure 2. Edible cricket protein (ECP) picture presented in the ECP+ informed condition ${ }^{\dagger} .{ }^{\dagger}$ Treatments are described in Figure 1.

\subsection{Statistical Analysis}

Data analyses were performed using the XLSTAT (Addinsoft, New York, NY, USA) statistical software version 2020 [26], R software version 4.0.3 (RStudio, Inc., Boston, MA, USA), and the Statistical Analysis Software (SAS) version 9.4 (Cary, NC, USA) with $\alpha=0.05$ significance level. Chocolate brownie treatments' sensory evaluation by subjects followed a balanced and randomized block design (panelists as blocks) with a factorial arrangement (formulation and informed condition factors with two-way interactions). Multi-way analysis of variance (ANOVA) with a mixed-effects model (demographics, liking moment (expected and actual), formulation and informed condition effects with up to three-way interactions between gender, formulation and informed condition and between liking moment, formulation, and informed condition as fixed effects, having panelists as a random effect), and a post hoc Tukey's HSD test $(p<0.05)$ were used to assess differences in the expected and actual hedonic ratings of the treatments. Principal Component Analysis (PCA) was used to elucidate the graphical relationship between treatments, expected and actual hedonic ratings. Agglomerative clustering analysis using the Euclidean-distance dissimilarity, Ward's linkage, and average silhouette width to determine the ideal number of clusters was applied to segment consumers' actual hedonic ratings into homogeneous liking profiles. Two-sided Cochran's $Q$ test followed by asymptotic McNemar test for post hoc multiple pairwise comparisons [27] with $p$-value adjusted by false discovery rate [28] was used to compare the frequencies of "likers" cluster across treatments segmented by gender. The proportion of "likers" across genders were compared with two-population proportions Z-tests. The same procedure (segmented by gender) was used to investigate if significant $(p<0.05)$ differences in consumption intent and purchase intent existed among the treatments and to compare the magnitude of the difference between consumption and purchase intent within treatments. The proportion of consumption and purchase intent across genders was compared for each treatment with two-population proportions Z-tests.

\section{Results and Discussion}

\subsection{Significance of Effects on Sensory Acceptability}

Sensory acceptability scores and results from analysis of variance (ANOVA) for the main and interaction effects are shown in Tables 1-3. The analysis of variance for the sensory liking variables (Table 1 ) showed that the gender effect (female or male) was only significant $(p<0.05)$ for texture liking and for overall flavor and overall liking $(\mathrm{OL})$ when interacting with formulation (CBWO or CBW). In general, male participants reported higher texture liking scores than female participants (disregarding all other main effects, 
Table 3). The levels of gender influenced the way overall flavor and OL of treatments were evaluated depending on formulations. The formulation effect was significant $(p<0.05)$ for all sensory liking variables studied (Table 1). Disregarding the informed condition, liking moment, and the other main effects, CBWO obtained higher liking scores than CBW $(\mathrm{CBWO}=6.65$ vs. $\mathrm{CBW}=6.38 ; \mathrm{CBWO}=6.72$ vs. $\mathrm{CBW}=6.52 ; \mathrm{CBWO}=6.41$ vs. $\mathrm{CBW}=5.98$; $\mathrm{CBWO}=6.61 \mathrm{vs} . \mathrm{CBW}=6.23 ; \mathrm{CBWO}=6.60 \mathrm{vs} . \mathrm{CBW}=6.26$ ) for appearance, aroma, texture, overall flavor, and OL, respectively (data derived from Table 2). Liking moment (expected or actual) and its interaction with formulation were significant $(p<0.05)$ for texture liking, overall flavor, and OL. Disregarding all the other effects, liking moment affected the liking of the texture, overall flavor, and OL of the treatments depending on the formulation level. Informed condition (ECP - or ECP+) effect was only significant $(p<0.05)$ for aroma and overall flavor liking; however, its two-way interaction with liking moment was significant $(p<0.05)$ not only for aroma and overall flavor liking but also for texture and OL. For aroma and overall flavor liking of the treatments, ECP - informed condition led to higher liking scores than the ECP+ informed condition $(\mathrm{ECP}-=6.68$ vs. $\mathrm{ECP}+=6.55 ; \mathrm{ECP}-=6.49$ vs. $\mathrm{ECP}+=6.36$, respectively; data derived from Table 2 ). For all the sensory attributes studied (except appearance), liking moment altered the way subjects rated their liking for the treatments depending on the informed condition level. The two-way interaction between formulation and informed condition was only significant $(p<0.05)$ for aroma liking (Table 1$)$.

\subsection{Effects of Formulation and Edible Cricket Protein and Benefits Disclosure on Sensory Acceptability}

Figure 3 depicts the separate contribution of formulation and informed condition effects to the observed variability across treatments in the sensory spectrum. The principal component 2 (explaining 37\% of the observed variability among treatments) mainly represents the expected acceptability, and, to a lesser extent, expected texture acceptability, and is more influenced by informed condition effect than by formulation. Table 2 presents the least squares means for expected (before tasting) and actual (after tasting) attributes' liking of treatments (Figure 1). When presenting formulations under the ECP-informed condition, appearance liking was higher for CBWO than for CBW, but when presenting them under the ECP+ informed condition, there was no difference across formulations, indicating a bias triggered by the informed condition and probably feelings driven by mental associations with entomophagy [29]. For either formulation (CBWO or CBW), expected flavor liking was higher $(p<0.05)$ for ECP - informed condition than for ECP+. Although the ECP+ informed condition contained information about environmental and nutritional benefits obtained from ECP consumption, it negatively impacted both brownie formulations' (CBWO and CBW) expected flavor liking. Lammers et al. [30] found similar results when studying the willingness to consume an insect burger and buffalo worms by German consumers and reported that sustainability awareness was not an important driver for the willingness to consume insects.

However, for expected aroma and OL, the ECP+ informed condition negatively impacted only CBWO (Table 2). Expected liking did not differ $(p>0.05)$ across genders (Table 3 ).

Participants' mindsets associated with food neophobia [31], disgust towards entomophagy [23], and other negative product-elicited emotions [32] may have contributed to the observed negative sensory-liking expectations for CBWO and flavor liking expectations for CBW when presented with ECP+ informed condition. Food neophobia and disgust emotion are the major mental constraints in the Western culture for the acceptability of entomophagy $[33,34]$. However, overcoming disgust emotion seems more challenging than prevailing over food neophobia because the familiarity of products containing insect protein can be improved through novel marketing campaigns such as advertising performed by "influencers" on social media platforms [30]. On the other hand, disgust emotion relies on existing associations between insects and other variables also considered disgusting, such as feces and decaying matter [35], which exert a higher predictive effect for the willingness to consume insects than neophobia [32]. 
Table 1. ANOVA ${ }^{\dagger}$ table for sensory acceptability $\ddagger$ of treatments $\S$.

\begin{tabular}{|c|c|c|c|c|c|c|c|c|c|c|}
\hline \multirow{2}{*}{ Effects } & \multicolumn{2}{|c|}{ Appearance * } & \multicolumn{2}{|c|}{ Aroma } & \multicolumn{2}{|c|}{ Texture } & \multicolumn{2}{|c|}{ Overall Flavor } & \multicolumn{2}{|c|}{ Overall Liking } \\
\hline & F Value & $P_{r}>F$ & F Value & $\mathbf{P}_{\mathrm{r}}>\mathrm{F}$ & F Value & $\mathbf{P}_{\mathrm{r}}>\mathrm{F}$ & F Value & $\mathbf{P}_{\mathrm{r}}>\mathrm{F}$ & F Value & $\mathbf{P}_{\mathrm{r}}>\mathrm{F}$ \\
\hline Gender & 1.54 & 0.22 & 0.01 & 0.91 & 4.33 & 0.04 & 3.49 & 0.06 & 2.54 & 0.11 \\
\hline Formulation & 39.34 & $<0.01$ & 13.38 & $<0.01$ & 50.79 & $<0.01$ & 39.64 & $<0.01$ & 35.00 & $<0.01$ \\
\hline Informed condition & 0.79 & 0.37 & 5.78 & 0.02 & 0.23 & 0.63 & 4.67 & 0.03 & 3.07 & 0.08 \\
\hline Liking moment*Formulation & - & - & 0.80 & 0.37 & 6.57 & 0.01 & 19.95 & $<0.01$ & 15.58 & $<0.01$ \\
\hline Liking momentInformed condition & - & - & 14.40 & $<0.01$ & 13.96 & $<0.01$ & 26.81 & $<0.01$ & 29.10 & $<0.01$ \\
\hline Formulation*Informed condition & 2.79 & 0.10 & 4.09 & 0.04 & 0.01 & 0.93 & 1.81 & 0.18 & 2.84 & 0.09 \\
\hline Gender*Formulation & 0.04 & 0.84 & 1.61 & 0.20 & 1.31 & 0.25 & 6.64 & 0.01 & 6.32 & 0.01 \\
\hline Gender*Informed condition & 0.03 & 0.87 & 0.47 & 0.49 & 0.03 & 0.85 & 0.21 & 0.65 & 0.35 & 0.55 \\
\hline Liking moment*Formulation*Informed condition & - & - & 1.25 & 0.26 & 1.00 & 0.32 & 0.22 & 0.64 & 0.00 & 0.98 \\
\hline Gender*Formulation*Informed condition & 0.11 & 0.74 & 1.14 & 0.29 & 0.00 & 0.96 & 0.25 & 0.62 & 0.16 & 0.69 \\
\hline
\end{tabular}

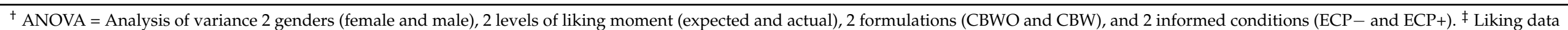

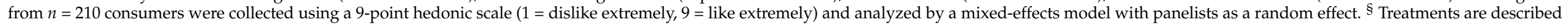
in Figure 1. * Appearance liking determined only before taste.

Table 2. Expected and actual sensory acceptability ${ }^{\dagger}$ of treatments $^{\ddagger}$.

\begin{tabular}{|c|c|c|c|c|c|c|c|c|c|}
\hline \multirow{2}{*}{$\begin{array}{c}\text { Treatments } \\
\text { Likings }\end{array}$} & \multicolumn{2}{|c|}{ CBWO- } & \multicolumn{2}{|c|}{ CBWO+ } & \multicolumn{2}{|c|}{ CBW- } & \multicolumn{2}{|c|}{ CBW+ } & \multirow{2}{*}{ SEM $\$$} \\
\hline & Expected & Actual & Expected & Actual & Expected & Actual & Expected & Actual & \\
\hline Appearance & \multicolumn{2}{|c|}{$6.67^{\mathrm{A}}$} & \multicolumn{2}{|c|}{$6.64^{\mathrm{A}}$} & \multicolumn{2}{|c|}{$6.33^{\mathrm{B}}$} & \multicolumn{2}{|c|}{$6.44^{\mathrm{AB}}$} & 0.28 \\
\hline Aroma & $6.90^{\mathrm{A}}$ & $6.77^{\mathrm{AB}}$ & $6.52^{\mathrm{BCD}}$ & $6.67^{\mathrm{ABCD}}$ & $6.70^{\mathrm{ABC}}$ & $6.36^{\mathrm{D}}$ & $6.42^{\mathrm{CD}}$ & $6.60^{\mathrm{ABCD}}$ & 0.25 \\
\hline Texture & $6.58^{\mathrm{A}}$ & $6.21^{\mathrm{BCD}}$ & $6.33^{\mathrm{ABC}}$ & $6.53^{\mathrm{AB}}$ & $6.25^{\mathrm{ABC}}$ & $5.68^{\mathrm{E}}$ & $6.10^{\mathrm{CD}}$ & $5.87^{\mathrm{DE}}$ & 0.31 \\
\hline Overall Flavor & $6.83^{\mathrm{A}}$ & $6.60^{\mathrm{ABC}}$ & $6.34^{\mathrm{BCD}}$ & $6.67^{\mathrm{AB}}$ & $6.67^{\mathrm{AB}}$ & $5.84^{\mathrm{E}}$ & $6.28^{\mathrm{CD}}$ & $6.13^{\mathrm{DE}}$ & 0.28 \\
\hline Overall Liking & $6.86^{\mathrm{A}}$ & $6.53^{\mathrm{AB}}$ & $6.35^{\mathrm{BC}}$ & $6.65^{\mathrm{AB}}$ & $6.65^{\mathrm{AB}}$ & $5.87^{\mathrm{D}}$ & $6.33^{\mathrm{BC}}$ & $6.17^{\mathrm{CD}}$ & 0.28 \\
\hline
\end{tabular}

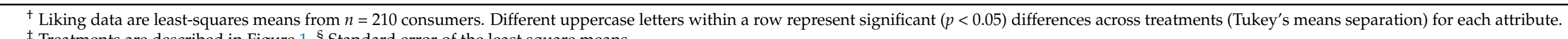

$\ddagger$ Treatments are described in Figure $1 .{ }^{\S}$ Standard error of the least square means. 
Table 3. Sensory acceptability ${ }^{\dagger}$ of treatments $^{\ddagger}$ by gender.

\begin{tabular}{|c|c|c|c|c|c|c|c|c|c|c|c|}
\hline \multirow{2}{*}{ Moment } & \multirow{2}{*}{$\begin{array}{c}\text { Treatments } \\
\text { Gender }\end{array}$} & \multicolumn{2}{|c|}{ CBWO- } & \multicolumn{2}{|c|}{ CBWO+ } & \multicolumn{2}{|c|}{ CBW- } & \multicolumn{2}{|c|}{ CBW+ } & \multicolumn{2}{|c|}{ SEM $\&$} \\
\hline & & Female & Male & Female & Male & Female & Male & Female & Male & Female & Male \\
\hline \multirow{5}{*}{ Expected (before tasting) } & Appearance & $6.56^{\mathrm{A}}$ & $6.78^{\mathrm{A}}$ & $6.54^{\mathrm{A}}$ & $6.74^{\mathrm{A}}$ & $6.24^{\mathrm{A}}$ & $6.41^{\mathrm{A}}$ & $6.33^{\mathrm{A}}$ & $6.54^{\mathrm{A}}$ & 0.30 & 0.31 \\
\hline & Aroma & $7.10^{\mathrm{AC}}$ & $6.96^{\mathrm{ABE}}$ & $6.64^{\mathrm{BDEF}}$ & $6.65^{\mathrm{ABCDEF}}$ & $6.90^{\mathrm{ABCD}}$ & $6.74^{\mathrm{ABCDEF}}$ & $6.54^{\mathrm{EF}}$ & $6.55^{\mathrm{CDF}}$ & 0.27 & 0.28 \\
\hline & Texture & $6.49^{\mathrm{A}}$ & $6.73^{\mathrm{A}}$ & $6.21^{\mathrm{AB}}$ & $6.50^{\mathrm{AB}}$ & $6.16^{\mathrm{AB}}$ & $6.38^{\mathrm{AB}}$ & $5.89^{\mathrm{B}}$ & $6.38^{\mathrm{AB}}$ & 0.31 & 0.32 \\
\hline & Overall Flavor & $6.74^{\mathrm{AB}}$ & $6.89^{\mathrm{A}}$ & $6.26^{\mathrm{C}}$ & $6.38^{\mathrm{BC}}$ & $6.57^{\mathrm{ABC}}$ & $6.71^{\mathrm{ABC}}$ & $6.18^{\mathrm{C}}$ & $6.33^{\mathrm{BC}}$ & 0.28 & 0.29 \\
\hline & Overall Liking & $6.83^{\mathrm{AB}}$ & $6.93^{\mathrm{A}}$ & $6.34^{\mathrm{C}}$ & $6.40^{\mathrm{BC}}$ & $6.61^{\mathrm{ABC}}$ & $6.71^{\mathrm{ABC}}$ & $6.27^{\mathrm{C}}$ & $6.43^{\mathrm{BC}}$ & 0.28 & 0.29 \\
\hline \multirow{4}{*}{ Actual (after tasting) } & Aroma & $6.75^{\mathrm{A}}$ & $6.53^{\mathrm{AB}}$ & $6.54^{\mathrm{AB}}$ & $6.55^{\mathrm{AB}}$ & $6.09^{\mathrm{B}}$ & $6.39^{\mathrm{AB}}$ & $6.45^{\mathrm{AB}}$ & $6.50^{\mathrm{AB}}$ & 0.30 & 0.31 \\
\hline & Texture & $6.00^{\mathrm{ABC}}$ & $6.36^{\mathrm{ABC}}$ & $6.37^{\mathrm{AB}}$ & $6.63^{\mathrm{A}}$ & $5.34^{\mathrm{D}}$ & $5.98^{\mathrm{BCD}}$ & $5.67^{\mathrm{CD}}$ & $6.01^{\mathrm{BCD}}$ & 0.37 & 0.38 \\
\hline & Overall Flavor & $6.57^{\mathrm{A}}$ & $6.67^{\mathrm{A}}$ & $6.62^{\mathrm{A}}$ & $6.77^{\mathrm{A}}$ & $5.44^{\mathrm{C}}$ & $6.31^{\mathrm{AB}}$ & $5.85^{\mathrm{BC}}$ & $6.47^{\mathrm{AB}}$ & 0.34 & 0.35 \\
\hline & Overall Liking & $6.45^{\mathrm{A}}$ & $6.58^{\mathrm{AB}}$ & $6.56^{\mathrm{A}}$ & $6.69^{\mathrm{A}}$ & $5.46^{\mathrm{C}}$ & $6.26^{\mathrm{AB}}$ & $5.90^{\mathrm{BC}}$ & $6.41^{\mathrm{AB}}$ & 0.34 & 0.36 \\
\hline
\end{tabular}

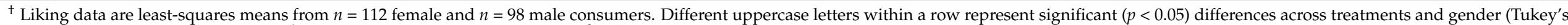
means separation) for each attribute. ${ }^{\ddagger}$ Treatments are described in Figure $1 . \$$ Standard error of the least square means. 


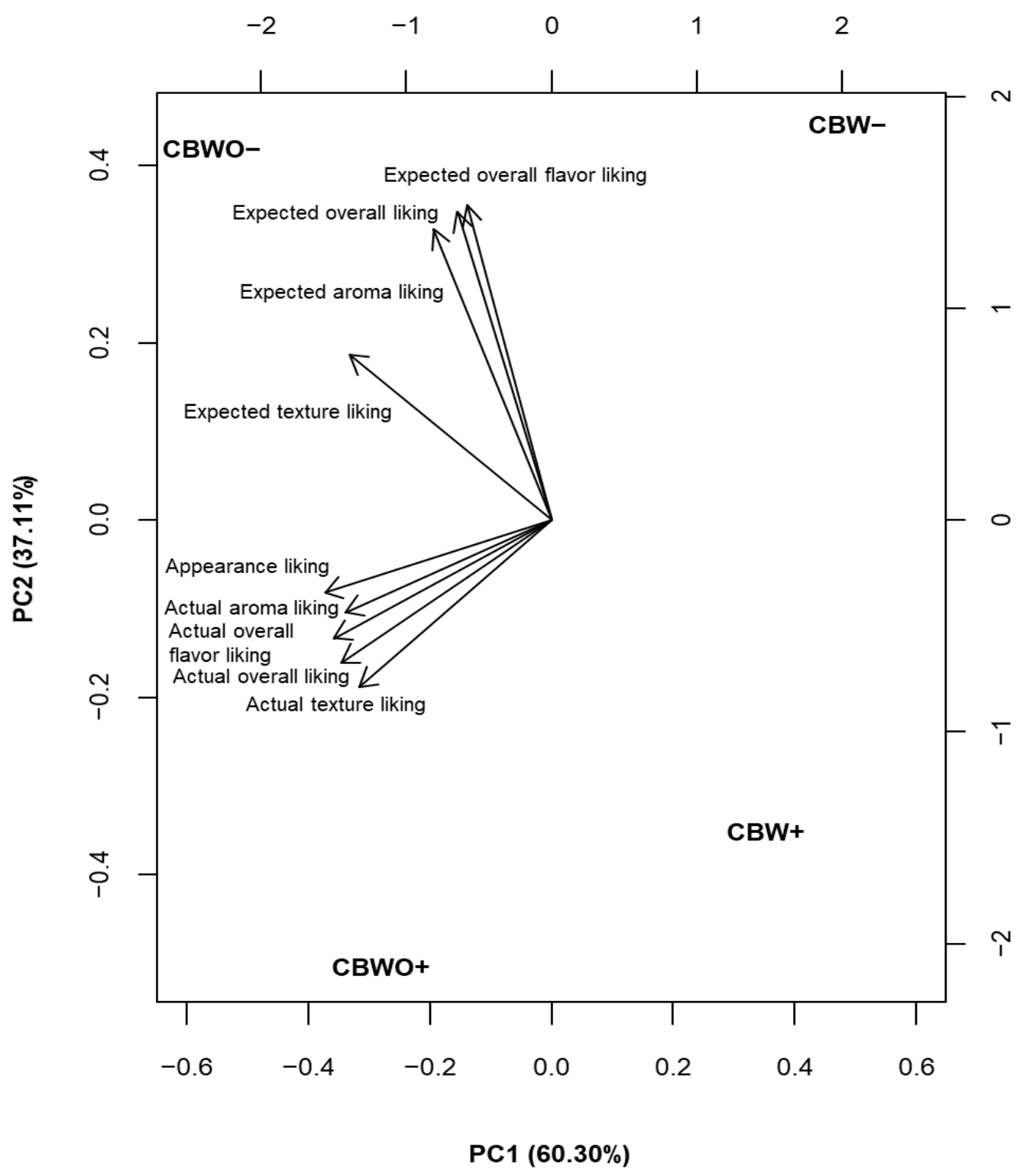

Figure 3. Principal component analysis (PCA) biplot visualizing expected and actual sensory liking and treatments ${ }^{\dagger} .{ }^{\dagger}$ Treatments are described in Figure 1.

Actual-liking scores were higher for CBWO than CBW for either informed condition (except for aroma when formulations were presented under ECP+ informed condition). Actual-liking scores were not significantly different between ECP - and ECP+ informed conditions for either formulation (CBWO and CBW; Table 2), showing a minimal effect of the informed conditions, which is also reflected in Figure 3 by the separation in terms of the principal component 1 (explaining $60 \%$ of the observed variability among treatments) mainly represented by formulation (CBWO- and CBWO+ on the left vs. CBW - and $\mathrm{CBW}+$ on the right side). Schouteten et al. [36] reported similar findings when studying the effect of the informed conditions (blind vs. informed about the ingredient composition showing benefits and food safety for insect ingredient) using burgers formulated with insect, plant-based, and meat-based ingredients. Insect-based vs. meat burgers differed in their sensory profiles regardless of the condition in which they were evaluated; insect-based burgers required further product development to improve their sensory quality. In the present study, the only significant difference across genders was observed in the liking for overall flavor and OL, which was lower for females than for males for CBW- (Table 3), 
possibly because females exhibited higher taste sensitivity towards ECP or lower tolerance to changes in chocolate flavor than males in the brownie formulation.

Despite the apparent minimal effect of the informed conditions, it influenced the disconfirmation mechanism for CBW and CBWO, which affects the perception and liking of foods [37-39]. Anderson [40] proposed four psychological mechanisms to explain the effect on product evaluation and customer satisfaction upon disconfirmed expectancy on the perceived product performance: (1) assimilation, (2) contrast, (3) assimilationcontrast, and (4) generalized negativity. Assimilation theory hypothesizes that individuals will try to match the perception of a product with their expectations. Contrast theory supposes an increment of the real difference between the actual product and the expected product, resulting in under-rating or over-rating of products compared to a scenario without expectations for negative and positive disconfirmation, respectively. Assimilationcontrast theory assumes existing limits for acceptance and rejection of products upon their perception. When the discrepancy between the expectation and actual perception of an attribute is sufficiently large, the product falls into the rejection region, leading to the abovementioned contrast effect. Instead, if the experienced discrepancy is too small, the product evaluation will take place based on the assimilation theory. Generalized negativity theorizes that a generalized hedonic state will occur if any disconfirmation occurs, leading to lower product ratings than if it had matched with expectations.

In this study, the contrast effect dominated the participants' evaluations when presenting $\mathrm{CBW}$ under $\mathrm{ECP}$ - informed condition, resulting in significant negative disconfirmation for all sensory attributes while for $\mathrm{CBWO}$, significant negative disconfirmation was observed only for texture. The observed negative disconfirmation for CBW when participants were informed no ECP was present neither its benefits $(\mathrm{ECP}-$ ) could be attributed to a "surprise effect". Because consumers were informed that no ECP was present in the formulation, they expected regular chocolate brownie's sensory properties and based their liking expectation on that piece of information and CBW- appearance. However, when noticing large differences in the sensory profile of CBW- compared to their expectations, a negative disconfirmation was driven possibly by the ECP "additional flavor" that occurred. On the other hand, the assimilation effect was more dominant when presenting both formulations (CBWO and $\mathrm{CBW})$ under the $\mathrm{ECP}+$ informed condition, resulting in non-significant disconfirmation because participants' mindset was already conditioned to taste something that they might or might not like.

Tan, Fischer, van Trijp and Stieger [33] reported higher sensory acceptability of novel foods, including insect-based foods after tasting compared to before tasting. Novel-food products such as chocolate brownies with ECP could benefit from attributes exhibiting no significant negative disconfirmation and positive disconfirmation (even if not significant). A mean liking score of 7 or higher on a nine-point hedonic scale is usually indicative of highly acceptable sensory quality [41], but considering the introduction of ECP to human diet represents a new concept for American consumers, CBW+ overall acceptability (actual $\mathrm{OL}=6.17$ ) seems a promising scenario for ECP incorporation into chocolate brownies whose formulation is yet to be optimized.

\subsection{Overall Differences in Sensory Acceptability Segmented by Gender}

Dimensions of actual liking were evaluated at the multivariate level jointly by clustering the panelists' actual liking for the treatments (Figure 4). Agglomerative clustering based on Euclidean distance dissimilarity using Ward's agglomeration method and average silhouette width to obtain the ideal number of clusters yielded two profiles for the subjects who evaluated the treatments, "dislikers" and "likers". The frequency of "likers" was compared across treatments based on gender. For females, the formulation was the leading factor for acceptability of the treatments while the informed condition was not. A significantly $(p<0.05)$ higher proportion of female likers for treatments without ECP $(\mathrm{CBWO}-=89 \%$ and $\mathrm{CBWO}+=90 \%)$ vs. those with $\mathrm{ECP}(\mathrm{CBW}-=71 \%$ and $\mathrm{CBW}+=74 \%)$ was observed. 


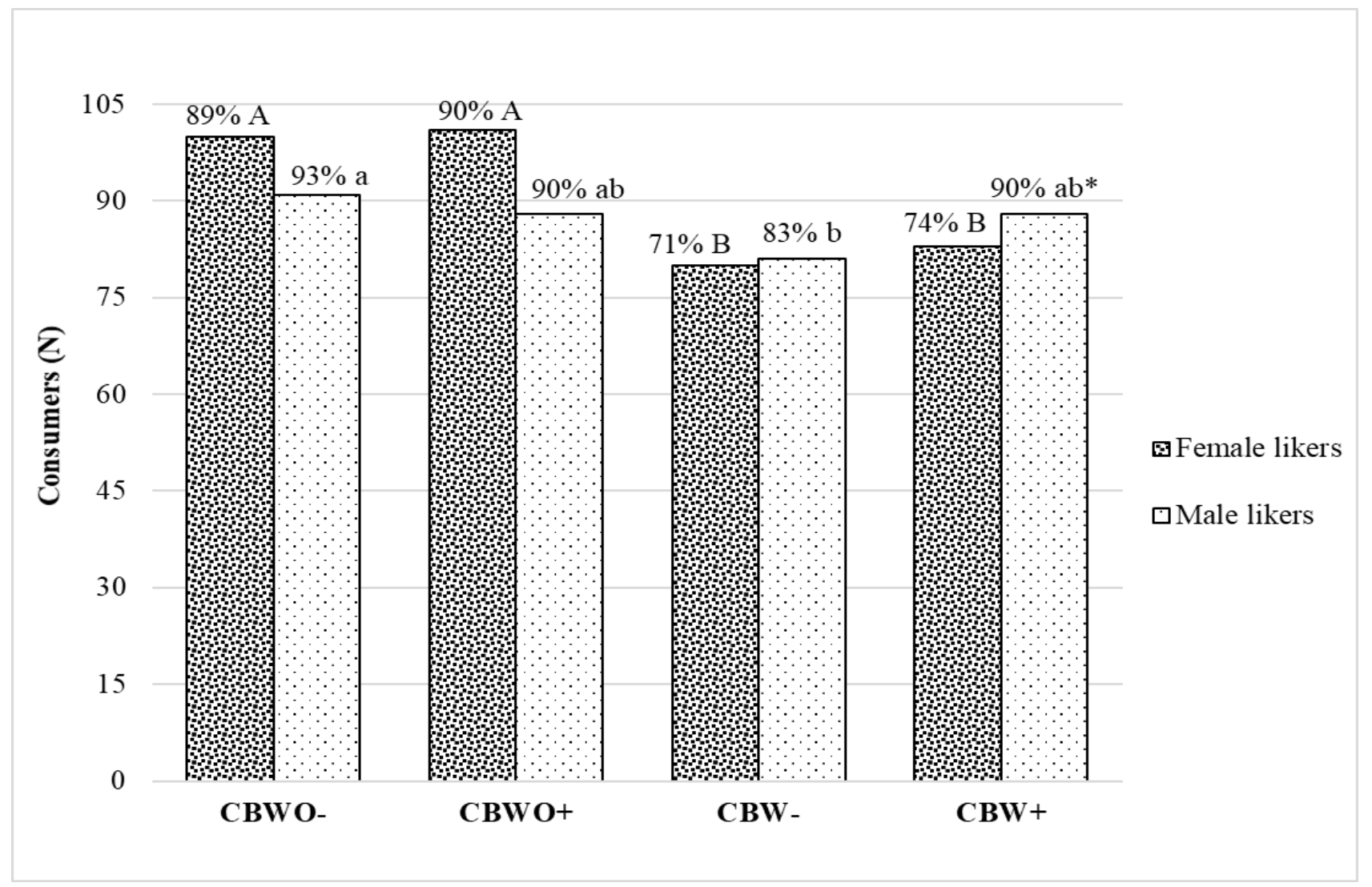

Figure 4. Likers and dislikers gender frequency plot across treatments ${ }^{\dagger}$. Data are frequencies of $n=112$ female and $n=98$ male consumers analyzed by Cochran's Q test with asymptotic McNemar test for post hoc multiple pairwise comparisons and $p$-value adjustment by false discovery rate. Liking clusters were determined through agglomerative clustering analysis from actual hedonic attributes rating applying Euclidean-distance dissimilarity, Ward's agglomeration method, and average silhouette width to determine the ideal number of clusters. ${ }^{+}$Treatments are described in Figure 1. Uppercase/lowercase letters represent a significant $(p<0.05)$ difference in the proportion of "likers" across treatments within female/male consumers. * Significant $(p<0.05)$ difference in "likers" proportion across genders $(Z$-test 2 population proportions).

On the contrary, the proportion of male likers was comparable across treatments without ECP (CBWO- and $\mathrm{CBWO}+$ ) and $\mathrm{CBW}+$, and treatments containing ECP (CBWand $\mathrm{CBW}+$ ) presented a similar proportion of likers to $\mathrm{CBWO}+$. These findings suggest a positive effect of the informed condition on the acceptability of chocolate brownies with ECP for male consumers.

Evidence of gender effect on the acceptability of edible insects is variable [42]. Some have found significant effects of gender on the acceptability of food containing edible insects $[25,34,43,44]$ while others have not [45,46]. A study by Megido, Gierts, Blecker, Brostaux, Haubruge, Alabi and Francis [25] with Belgian students (18-25 years old) reported a significant effect of gender (males exhibited less neophobic behavior than women) in addition to familiarity with edible insects, product appearance, and taste on the overall liking of hybrid insect-based burgers. Similarly, in a cross-sectional study with Belgian non-vegetarian subjects involved in food purchase, Verbeke [34] found that males were more willing to incorporate edible insects into their diets than females, and individuals who wished to reduce meat consumption had a strong orientation toward convenience foods and were concerned about the environmental impact of their food choices. On the other hand, consumers who enjoyed the taste of meat and were convinced of its health benefits were less likely to incorporate edible insects into their diets. In the online survey study about attitudes toward food conducted by Ruby, Rozin and Chan [43], men's readiness 
to taste edible insects was higher than for females, mainly in the U.S. Disgust emotion, notions of benefits, sensation seeking, and pleasure of telling others about consumption of unusual foods were significant parameters for the prediction of edible insects' acceptability.

\subsection{Consumption and Purchase Intent Segmented by Gender}

The frequency distribution for consumption and purchase intent by gender is shown in Figure 5. For females, a similar scenario to overall product sensory acceptability described above was observed. Treatments containing ECP (CBW- and CBW+) had a lower $(p<0.05)$ frequency of consumption intent than those without ECP (CBWO- and CBWO+) regardless of the informed condition. On the contrary, males had a similar frequency of consumption intent across all treatments. Females may have had lower thresholds for the detection or recognition of ECP in the brownie formulation than males [47] or male consumers while recognizing a difference in the sensory properties of treatments with $\mathrm{ECP}$, but still presented the same willingness to consume them as for those without ECP because males had higher blind acceptability for ECP than women [48-50].

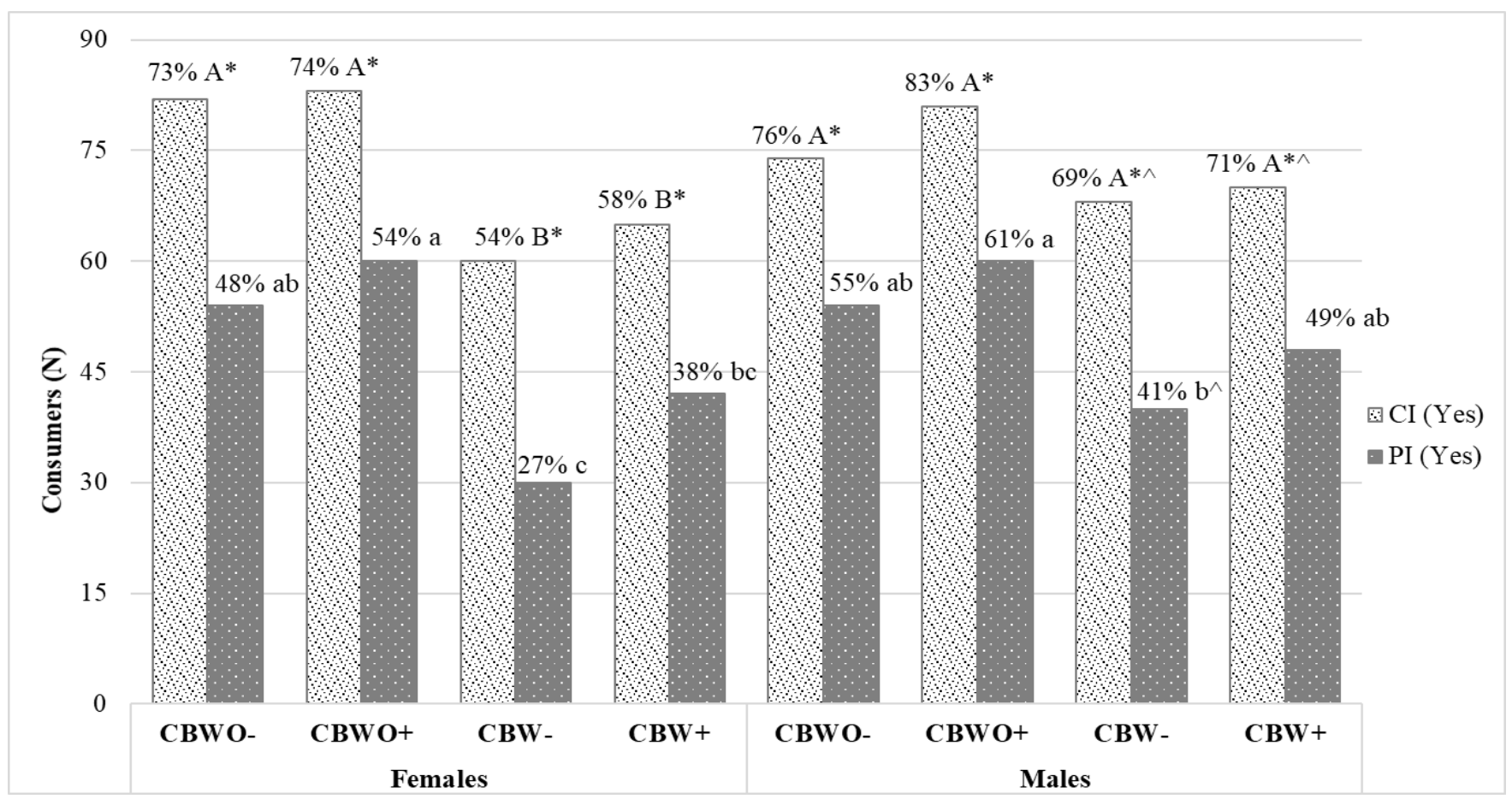

Figure 5. Gender's consumption intent and purchase intent plot across treatments ${ }^{\dagger}$. Data are frequencies of "Yes" responses per treatment from $n=112$ female and $n=98$ male consumers analyzed by Cochran's $Q$ test with asymptotic McNemar test for post hoc multiple pairwise comparisons and $p$-value adjustment by false discovery rate. ${ }^{\dagger}$ Treatments are described in Figure 1. Uppercase/lowercase letters represent significantly $(p<0.05)$ different consumption intent/purchase intent frequencies across treatments for each gender. * Significant $(p<0.05)$ difference across purchase intent and consumption intent within treatments for each gender. ^ Significant $(p<0.05)$ difference in consumption intent/purchase intent frequencies across genders (Z-test 2 population proportions) within treatments.

Regarding purchase intent, females exhibited higher $(p<0.05)$ frequency for treatments without $\mathrm{ECP}(\mathrm{CBWO}-$ and $\mathrm{CBWO}+)$, but the treatment containing ECP and the informed condition $(\mathrm{CBW}+)$ achieved similar purchase intent to $\mathrm{CBWO}-$, demonstrating a positive effect of the informed condition (purchase intent increased from $27 \%$ for CBW- to $38 \%$ for $\mathrm{CBW}+$; Figure 5). For males, the purchase intent frequency was significantly lower only for $\mathrm{CBW}$ - when compared to CBWO+. In this scenario, the informed condition (ECP+) in $\mathrm{CBW}$ allowed $\mathrm{CBW}+$ to achieve comparable purchase intent to that of $\mathrm{CBWO}-$ and CBWO+. This suggests that there is a greater positive effect of the informed condition towards the willingness to pay for brownies containing ECP in males than in females [51]. 
Drivers for this behavior in males may include increased sensation-seeking, which is related to an individual's disinhibition, experience-seeking, susceptibility to boredom, and tendency to seek thrill and adventure [43] or experiencing less disgust [52]. These results agree with the aforementioned section regarding males' overall product sensory acceptability. However, all treatments presented a significant $(p<0.05)$ discrepancy in the frequency of consumption intent vs. purchase intent, with the consumption intent proportion higher. This behavior could be partly explained by the need for improvement in terms of formulation for all brownies, not only those containing ECP [53]. This may suggest that consumers may be ready to experience tasting products formulated with edible insects [23] but are not necessarily willing to pay for them as this involves the consumers' perceived importance of the ECP benefits and their socioeconomic status.

Some studies report a significant effect of communicating benefits about entomophagy towards improving edible insects' acceptability and participants' willingness to taste $[35,43,51,54,55]$, which is dependent on the subjects' degree of environmental consciousness [34,56-60], while others found it insufficient to promote their acceptability $[46,50,61,62]$. However, a consumption intent above $50 \%$ and a purchase intent of $49 \%$ achieved by CBW+ among males offer a promising scenario when still being in the introductory stage for this kind of novel product.

\section{Conclusions and Future Studies}

This research investigated consumers' hedonic perceptions, consumption, and purchase behaviors towards ECP contained in familiar chocolate brownies. The acceptability of ECP in chocolate brownies differed across genders, with males being more likely to consume and purchase chocolate brownies containing ECP than females. Although formulation affected actual liking of chocolate brownies more than the informed condition, the latter prevented significant negative disconfirmation for all sensory attributes in chocolate brownies containing ECP. The actual OL obtained for CBW+ (regardless of gender) suggests a promising scenario for the incorporation of ECP into similar products as well as products consumers are willing to try. Moreover, informing consumers about the presence and nutritional and environmental benefits of ECP $(\mathrm{ECP}+)$ positively impacted the purchase intent of CBW among females, while among males it decreased the sensory liking differences among formulations favoring the proportion of likers for CBW. As consumption of edible insects among Westerners is very limited, information regarding edible insects and their consumption, including safety, environmental impact, and nutritional benefits may improve familiarity and alleviate aversion to entomophagy. Therefore, the findings from this study may be helpful to guide future development of products incorporated with ECP for the Westerner diets.

For future studies, differences between samples regarding texture and flavor should be further investigated and characterized either with a traditional descriptive analysis with trained panelists or with novel rapid methods such as a consumer based CATA descriptive panel [63]. Once key sensory attributes have been identified in brownies containing ECP, another consumer study involving the intensity perception of such attributes could be conducted to determine which are responsible for the observed differences in acceptability across formulations. Evaluating different ECP suppliers through a descriptive profile is highly recommended to identify key attributes and their ideal levels through consumer rejection threshold studies. Lastly, evaluating the emotional profile of treatments in a complementary way to hedonic discrimination to identify drivers of liking and important product-elicited emotions that predict acceptability, consumption, and purchase behavior is recommended.

Author Contributions: Conceptualization, C.E.G., D.D.T., B.L., G.T. and W.P.; performing the research work, C.E.G.; data analysis and interpretation, C.E.G., D.D.T., B.L., G.T. and W.P.; writingoriginal draft preparation, C.E.G.; writing—review and editing, C.E.G., D.D.T., B.L., G.T. and W.P.; supervision, W.P.; project administration and resource/funding acquisition, W.P. All authors have read and agreed to the published version of the manuscript. 
Funding: This work was partially supported by the USDA National Institute of Food and Agriculture Hatch project (Accession No. 1022270; Hatch Project No. LAB94473) and the LSU AgCenter.

Institutional Review Board Statement: The study was conducted according to the guidelines of the Declaration of Helsinki and approved by the Institutional Review Board of Louisiana State University Agricultural Center (IRB \# HE 18-9 and IRB \# HE 18-22).

Informed Consent Statement: Informed consent was obtained from all subjects involved in the study.

Data Availability Statement: The data that support the findings of this study are available from the corresponding author upon reasonable request.

Acknowledgments: We acknowledge the graduate students in the Sensory Services Lab, LSU AgCenter for assistance with the lab work.

Conflicts of Interest: All authors declare no conflicts of interest. The funders had no role in the design of the study; in the collection, analyses, or interpretation of data; in the writing of the manuscript, or in the decision to publish the results.

\section{References}

1. Wu, G.; Fanzo, J.; Miller, D.D.; Pingali, P.; Post, M.; Steiner, J.L.; Thalacker-Mercer, A.E. Production and supply of high-quality food protein for human consumption: Sustainability, challenges, and innovations. Ann. N. Y. Acad. Sci. 2014, 1321, 1-19. [CrossRef]

2. Belluco, S.; Losasso, C.; Maggioletti, M.; Alonzi, C.C.; Paoletti, M.G.; Ricci, A. Edible insects in a food safety and nutritional perspective: A critical review. Compr. Rev. Food Sci. Food Saf. 2013, 12, 296-313. [CrossRef]

3. Glover, D.; Sexton, A. Edible Insects and the Future of Food: A Foresight Scenario Exercise on Entomophagy and Global Food Security; IDS: Sussex, UK, 2015.

4. Kouřimská, L.; Adámková, A. Nutritional and sensory quality of edible insects. NFS J. 2016, 4, 22-26. [CrossRef]

5. Ghosh, S.; Jung, C.; Meyer-Rochow, V.B. What governs selection and acceptance of edible insect species? In Edible Insects in Sustainable Food Systems; Springer: Berlin/Heidelberg, Germany, 2018; pp. 331-351.

6. Melgar-Lalanne, G.; Hernández-Álvarez, A.J.; Salinas-Castro, A. Edible insects processing: Traditional and innovative technologies. Compr. Rev. Food Sci. Food Saf. 2019, 18, 1166-1191. [CrossRef] [PubMed]

7. Rumpold, B.A.; Schlüter, O.K. Nutritional composition and safety aspects of edible insects. Mol. Nutr. Food Res. 2013, 57, 802-823. [CrossRef] [PubMed]

8. Churchward-Venne, T.A.; Pinckaers, P.J.; van Loon, J.J.; van Loon, L.J. Consideration of insects as a source of dietary protein for human consumption. Nutr. Rev. 2017, 75, 1035-1045. [CrossRef] [PubMed]

9. Imathiu, S. Benefits and food safety concerns associated with consumption of edible insects. NFS J. 2020, 18, 1-11. [CrossRef]

10. Raubenheimer, D.; Rothman, J.M. Nutritional ecology of entomophagy in humans and other primates. Annu. Rev. Entomol. 2013, 58, 141-160. [CrossRef]

11. Finke, M.D.; DeFoliart, G.R.; Benevenga, N.J. Use of a four-parameter logistic model to evaluate the quality of the protein from three insect species when fed to rats. J. Nutr. 1989, 119, 864-871. [CrossRef]

12. Köhler, R.; Kariuki, L.; Lambert, C.; Biesalski, H. Protein, amino acid and mineral composition of some edible insects from Thailand. J. Asia Pac. Entomol. 2019, 22, 372-378. [CrossRef]

13. Oibiokpa, F.I.; Akanya, H.O.; Jigam, A.A.; Saidu, A.N.; Egwim, E.C. Protein quality of four indigenous edible insect species in Nigeria. Food Sci. Hum. Wellness 2018, 7, 175-183. [CrossRef]

14. de Castro, R.J.S.; Ohara, A.; dos Santos Aguilar, J.G.; Domingues, M.A.F. Nutritional, functional and biological properties of insect proteins: Processes for obtaining, consumption and future challenges. Trends Food Sci. Technol. 2018, 76, 82-89. [CrossRef]

15. Ardoin, R.; Prinyawiwatkul, W. Product Appropriateness, Willingness to Try, and Perceived Risks of Foods Containing Insect Protein Powder: A Survey of US Consumers. Int. J. Food Sci. Technol. 2020, 55, 3215-3226. [CrossRef]

16. Ardoin, R.; Romero, R.; Marx, B.; Prinyawiwatkul, W. Exploring New and Modified Rejection-Type Thresholds Using Cricket Snack Crackers. Foods 2020, 9, 1352. [CrossRef]

17. Van Huis, A.; Dicke, M.; van Loon, J.J. Insects to feed the world. J. Insects Food Feed 2015, 1, 3-5. [CrossRef]

18. Shelomi, M. Why we still don't eat insects: Assessing entomophagy promotion through a diffusion of innovations framework. Trends Food Sci. Technol. 2015, 45, 311-318. [CrossRef]

19. Giordano, S.; Clodoveo, M.L.; De Gennaro, B.; Corbo, F. Factors determining neophobia and neophilia with regard to new technologies applied to the food sector: A systematic review. Int. J. Gastron. Food Sci. 2018, 11, 1-19. [CrossRef]

20. Ardoin, R.; Prinyawiwatkul, W. Consumer Perceptions of Insect Consumption: A Review of Western Research since 2015. Int. J. Food Sci. Technol. 2021. [CrossRef]

21. Ardoin, R.; Marx, B.D.; Boeneke, C.; Prinyawiwatkul, W. Effects of cricket powder on selected physical properties and US consumer perceptions of whole-wheat snack crackers. Int. J. Food Sci. Technol. 2021. [CrossRef]

22. Berger, S.; Bärtsch, C.; Schmidt, C.; Christandl, F.; Wyss, A.M. When utilitarian claims backfire: Advertising content and the uptake of insects as food. Front. Nutr. 2018, 5, 88. [CrossRef] 
23. Mishyna, M.; Chen, J.; Benjamin, O. Sensory attributes of edible insects and insect-based foods-Future outlooks for enhancing consumer appeal. Trends Food Sci. Technol. 2020, 95, 141-148. [CrossRef]

24. Fischer, A.R.; Steenbekkers, L.B. All insects are equal, but some insects are more equal than others. Br. Food J. 2018. [CrossRef] [PubMed]

25. Megido, R.C.; Gierts, C.; Blecker, C.; Brostaux, Y.; Haubruge, É.; Alabi, T.; Francis, F. Consumer acceptance of insect-based alternative meat products in Western countries. Food Qual. Prefer. 2016, 52, 237-243. [CrossRef]

26. Addinsoft. XLSTAT Statistical and Data Analysis Solution. Available online: https:/ /www.xlstat.com (accessed on 15 June 2021$)$.

27. Smith, M.Q.P.; Ruxton, G.D. Effective use of the McNemar test. Behav. Ecol. Sociobiol. 2020, 74, 1-9.

28. Benjamini, Y.; Hochberg, Y. Controlling the false discovery rate: A practical and powerful approach to multiple testing. J. R. Stat. Soc. Ser. B (Methodol.) 1995, 57, 289-300. [CrossRef]

29. Woolf, E.; Zhu, Y.; Emory, K.; Zhao, J.; Liu, C. Willingness to consume insect-containing foods: A survey in the United States. LWT 2019, 102, 100-105. [CrossRef]

30. Lammers, P.; Ullmann, L.M.; Fiebelkorn, F. Acceptance of insects as food in Germany: Is it about sensation seeking, sustainability consciousness, or food disgust? Food Qual. Prefer. 2019, 77, 78-88. [CrossRef]

31. La Barbera, F.; Verneau, F.; Coppola, A. Entomophagy: A contribution to the understanding of consumer intention. Calitatea 2019, 20, 329-334.

32. La Barbera, F.; Verneau, F.; Amato, M.; Grunert, K. Understanding Westerners' disgust for the eating of insects: The role of food neophobia and implicit associations. Food Qual. Prefer. 2018, 64, 120-125. [CrossRef]

33. Tan, H.S.G.; Fischer, A.R.; van Trijp, H.C.; Stieger, M. Tasty but nasty? Exploring the role of sensory-liking and food appropriateness in the willingness to eat unusual novel foods like insects. Food Qual. Prefer. 2016, 48, 293-302. [CrossRef]

34. Verbeke, W. Profiling consumers who are ready to adopt insects as a meat substitute in a Western society. Food Qual. Prefer. 2015, 39, 147-155. [CrossRef]

35. Verneau, F.; La Barbera, F.; Kolle, S.; Amato, M.; Del Giudice, T.; Grunert, K. The effect of communication and implicit associations on consuming insects: An experiment in Denmark and Italy. Appetite 2016, 106, 30-36. [CrossRef]

36. Schouteten, J.J.; De Steur, H.; De Pelsmaeker, S.; Lagast, S.; Juvinal, J.G.; De Bourdeaudhuij, I.; Verbeke, W.; Gellynck, X. Emotional and sensory profiling of insect-, plant-and meat-based burgers under blind, expected and informed conditions. Food Qual. Prefer. 2016, 52, 27-31. [CrossRef]

37. Laguna, L.; Gómez, B.; Garrido, M.D.; Fiszman, S.; Tarrega, A.; Linares, M.B. Do Consumers Change Their Perception of Liking, Expected Satiety, and Healthiness of a Product If They Know It Is a Ready-to Eat Meal? Foods 2020, 9, 1257. [CrossRef] [PubMed]

38. Santagiuliana, M.; Bhaskaran, V.; Scholten, E.; Piqueras-Fiszman, B.; Stieger, M. Don't judge new foods by their appearance! How visual and oral sensory cues affect sensory perception and liking of novel, heterogeneous foods. Food Qual. Prefer. 2019, 77, 64-77. [CrossRef]

39. Verastegui-Tena, L.; van Trijp, H.; Piqueras-Fiszman, B. Heart rate, skin conductance, and explicit responses to juice samples with varying levels of expectation (dis) confirmation. Food Qual. Prefer. 2019, 71, 320-331. [CrossRef]

40. Anderson, R.E. Consumer dissatisfaction: The effect of disconfirmed expectancy on perceived product performance. J. Mark. Res. 1973, 10, 38-44. [CrossRef]

41. Everitt, M. Consumer-targeted sensory quality. In Global Issues in Food Science and Technology; Elsevier: Amsterdam, The Netherlands, 2009; pp. 117-128.

42. Hartmann, C.; Siegrist, M. Insects as food: Perception and acceptance. Findings from current research. Ernahr. Umsch. 2017, $64,44-50$.

43. Ruby, M.B.; Rozin, P.; Chan, C. Determinants of willingness to eat insects in the USA and India. J. Insects Food Feed 2015, 1, 215-225. [CrossRef]

44. Schösler, H.; De Boer, J.; Boersema, J.J. Can we cut out the meat of the dish? Constructing consumer-oriented pathways towards meat substitution. Appetite 2012, 58, 39-47. [CrossRef]

45. de Boer, J.; Schösler, H.; Boersema, J.J. Motivational differences in food orientation and the choice of snacks made from lentils, locusts, seaweed or "hybrid" meat. Food Qual. Prefer. 2013, 28, 32-35. [CrossRef]

46. Hartmann, C.; Shi, J.; Giusto, A.; Siegrist, M. The psychology of eating insects: A cross-cultural comparison between Germany and China. Food Qual. Prefer. 2015, 44, 148-156. [CrossRef]

47. Mitchell, M.; Brunton, N.P.; Wilkinson, M.G. The influence of salt taste threshold on acceptability and purchase intent of reformulated reduced sodium vegetable soups. Food Qual. Prefer. 2013, 28, 356-360. [CrossRef]

48. Castro Delgado, M.; Chambers IV, E.; Carbonell-Barrachina, A.; Noguera Artiaga, L.; Vidal Quintanar, R.; Burgos Hernandez, A. Consumer acceptability in the USA, Mexico, and Spain of chocolate chip cookies made with partial insect powder replacement. J. Food Sci. 2020, 85, 1621-1628. [CrossRef] [PubMed]

49. Orsi, L.; Voege, L.L.; Stranieri, S. Eating edible insects as sustainable food? Exploring the determinants of consumer acceptance in Germany. Food Res. Int. 2019, 125, 108573. [CrossRef]

50. Schäufele, I.; Albores, E.B.; Hamm, U. The role of species for the acceptance of edible insects: Evidence from a consumer survey. Br. Food J. 2019. [CrossRef]

51. Barsics, F.; Megido, R.C.; Brostaux, Y.; Barsics, C.; Blecker, C.; Haubruge, E.; Francis, F. Could new information influence attitudes to foods supplemented with edible insects? Br. Food J. 2017. [CrossRef] 
52. Hamerman, E.J. Cooking and disgust sensitivity influence preference for attending insect-based food events. Appetite 2016, 96, 319-326. [CrossRef]

53. Tan, H.S.G.; Verbaan, Y.T.; Stieger, M. How will better products improve the sensory-liking and willingness to buy insect-based foods? Food Res. Int. 2017, 92, 95-105. [CrossRef]

54. Balzan, S.; Fasolato, L.; Maniero, S.; Novelli, E. Edible insects and young adults in a north-east Italian city an exploratory study. Br. Food J. 2016. [CrossRef]

55. Caparros Megido, R.; Sablon, L.; Geuens, M.; Brostaux, Y.; Alabi, T.; Blecker, C.; Drugmand, D.; Haubruge, É.; Francis, F. Edible Insects Acceptance by B elgian Consumers: Promising Attitude for Entomophagy Development. J. Sens. Stud. 2014, 29 , 14-20. [CrossRef]

56. Gamborg, C.; Röcklinsberg, H.; Gjerris, M. Sustainable proteins? Values related to insects in food systems. In Edible Insects in Sustainable Food Systems; Springer: Berlin/Heidelberg, Germany, 2018; pp. 199-211.

57. Lensvelt, E.J.; Steenbekkers, L. Exploring consumer acceptance of entomophagy: A survey and experiment in Australia and the Netherlands. Ecol. Food Nutr. 2014, 53, 543-561. [CrossRef] [PubMed]

58. Schiemer, C.; Halloran, A.; Jespersen, K.; Kaukua, P. Marketing Insects: Superfood or Solution-Food? In Edible Insects in Sustainable Food Systems; Springer: Berlin/Heidelberg, Germany, 2018; pp. 213-236.

59. Tan, H.S.G.; Fischer, A.R.; Tinchan, P.; Stieger, M.; Steenbekkers, L.; van Trijp, H.C. Insects as food: Exploring cultural exposure and individual experience as determinants of acceptance. Food Qual. Prefer. 2015, 42, 78-89. [CrossRef]

60. Kostecka, J.; Konieczna, K.; Cunha, L.M. Evaluation of insect-based food acceptance by representatives of polish consumers in the context of natural resources processing retardation. J. Ecol. Eng. 2017, 18, 166-174. [CrossRef]

61. Sogari, G.; Bogueva, D.; Marinova, D. Australian consumers' response to insects as food. Agriculture 2019, 9, 108. [CrossRef]

62. Van Huis, A.; Van Itterbeeck, J.; Klunder, H.; Mertens, E.; Halloran, A.; Muir, G.; Vantomme, P. Edible Insects: Future Prospects for Food and Feed Security; Food and Agriculture Organization of the United Nations: Rome, Italy, 2013.

63. Delicato, C.; Schouteten, J.J.; Dewettinck, K.; Gellynck, X.; Tzompa-Sosa, D.A. Consumers' perception of bakery products with insect fat as partial butter replacement. Food Qual. Prefer. 2020, 79, 103755. [CrossRef] 